\title{
The lateral recumbent head-down position decreases the incidence of epidural venous punc- ture during catheter insertion in obese parturients
} [La position de Trendelenburg latéral diminue l'incidence de ponction veineuse épidurale pendant l'insertion d'un cathéter chez des parturientes obèses]

Murat Bahar MD, ${ }^{*}$ Michael Chanimov MD PhD, ${ }^{*}$ Mathias L. Cohen MB CHB, ${ }^{*}$ Mark Friedland MD, ${ }^{*}$ Ina Shul MD, Vladislav Gofman MD, ${ }^{*}$ Shlomo Gershfeld MD, ${ }^{*}$ Rima Geller MD, ${ }^{*}$ Dan J. Sherman MD $\dagger$

Purpose: The unintentional and unrecognized cannulation of an extradural vein is a potentially serious complication of an epidural anesthetic. The present study was undertaken to assess the incidence of blood vessel puncture related to epidural catheterization in three different body positions, in a cohort of morbidly obese parturients, following the completion of a similar study published in 200I from which such parturients were excluded.

Methods: The study was conducted in 450 (three groups of 150) morbidly obese, obstetric patients undergoing continuous epidural analgesia during labour. Epidural catheterization was performed on patients randomized to the sitting, lateral recumbent horizontal, or lateral recumbent head-down position.

Results: There was a lower incidence of vessel cannulation when this procedure was performed in the lateral recumbent head-down position [1.3\%; body mass index (BMI): 37.0] than in the lateral recumbent horizontal [12.9\%; BMI: 38.0] and in the sitting position [I2.0\%; BMI: 38.0]. The incidence of accidental subarachnoid puncture was $2 \%, 1.3 \%$ and $2 \%$ respectively, in these same positions.

Conclusion: Adoption of the lateral recumbent head-down position for the performance of lumbar epidural blockade, in labour at term, reduces the incidence of lumbar epidural venous puncture in these obese parturients.

Objectif : La canulation accidentelle et inaperçue d'une veine extradurale est une complication grave possible de l'anesthésie épidurale. Nous avons voulu évaluer l'incidence de ponction vasculaire reliée à la cathétérisation épidurale selon trois différentes positions du corps de parturientes avec obésité morbide, pour donner suite à une étude similaire publiée en 2001 et de laquelle ces parturientes avaient été exclues.

Méthode : L'étude a été menée chez 450 (trois groupes de 150) patientes d'obstétriques très obèses devant subir une analgésie épidurale continue pendant le travail obstétrical. La cathétérisation a été réalisée chez les patientes randomisées pour adopter la position assise, décubitus latéral ou Trendelenburg latéral.

Résultats : L'incidence de canulation vasculaire était plus faible en position de Trendelenburg latéral [1,3\% ; indice de masse corporelle (IMC) : 37,0] qu'en décubitus latéral [12,9\%; IMC : 38,0] ou en position assise [12,0\%; IMC : 38,0]. L'incidence de ponction sousarachnoïdienne était de $2 \%, 1,3 \%$ et $2 \%$ respectivement, dans ces mêmes positions.

Conclusion : L'adoption de la position de Trendelenburg latéral pour réaliser le bloc épidural lombaire, au terme du travail, réduit l'incidence de ponction veineuse épidurale lombaire chez ces patientes obèses.

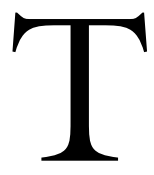
HE unintentional, unrecognized cannulation of an epidural vein is a potentially serious complication of epidural anesthesia. The present study was undertaken to assess the incidence of blood vessel puncture during epidural catheterization in three different positions, in a cohort of morbidly obese parturients. A similar study in nonobese parturients, from which morbidly obese women were excluded, found that adoption of the lateral

From the Departments of Anesthesiology, ${ }^{*}$ and Obstetrics and Gynecology, $†$ Assaf Harofeh Medical Center, Zerifin, Sackler Faculty of Medicine, Tel-Aviv University, Tel-Aviv, Israel. Address correspondence to: Dr. Murat Bahar, Department of Anesthesiology, Assaf Harofeh Medical Center, Zerifin 70300, Israel.

Phone: +972-8-9977466; Fax: +972-8-9779459; E-mail: anesthesia@asaf.health.gov.il

Assessed April 23, 2003.

Revision accepted September 5, 2003

Final revision accepted February 18, 2004. 
TABLE I Prevalence of secondary outcomes in the three study groups

\begin{tabular}{|c|c|c|c|c|}
\hline & Sitting position & $\begin{array}{l}\text { Lateral recumbent } \\
\text { horizontal position }\end{array}$ & $\begin{array}{l}\text { Lateral recumbent } \\
\text { head-down position }\end{array}$ & P value \\
\hline Sample size & 150 & 150 & 150 & \\
\hline Blood in catheter & $20(12.0 \%)$ & $11(7.3 \%)$ & $3(1.3 \%)$ & 0.001 \\
\hline Blood in needle & $5(3.3 \%)$ & $3(1.9 \%)$ & $1(1.3 \%)$ & NS \\
\hline Unintended subarachnoid puncture & $3(2.0 \%)$ & $2(1.3 \%)$ & $3(2.0 \%)$ & NS \\
\hline
\end{tabular}

TABLE II Comparison of background variables

\begin{tabular}{|c|c|c|c|c|}
\hline \multicolumn{2}{|l|}{ Background variable } & \multirow{2}{*}{$\begin{array}{l}\text { Sitting } \\
\text { position }\end{array}$} & \multirow{2}{*}{$\begin{array}{l}\text { Lateral recumbent } \\
\text { borizontal position }\end{array}$} & \multirow{2}{*}{$\begin{array}{l}\text { Lateral recumbent } \\
\text { head-down position } \\
37.0\end{array}$} \\
\hline BMI: & Avg & & & \\
\hline & SD & \pm 3.3 & \pm 5.3 & \pm 4.4 \\
\hline Distance & Avg & $6.3 \mathrm{~cm}$ & $6.2 \mathrm{~cm}$ & $6.2 \mathrm{~cm}$ \\
\hline from skin to epidural space & SD & \pm 1.7 & \pm 1.9 & \pm 1.8 \\
\hline Number of previous & Avg & 4.0 & 3.7 & 4.5 \\
\hline labours (parity) & SD & \pm 2.6 & \pm 2.7 & \pm 3.1 \\
\hline Attempts $>1$ & & $16.6 \%$ & $15.5 \%$ & $16.0 \%$ \\
\hline
\end{tabular}

$\mathrm{BMI}=$ body mass index $;$ Avg = average $\mathrm{SD}=$ standard deviation.

recumbent head-down position, for the performance of the lumbar epidural blockade in labour at term reduces the incidence of epidural venous puncture. ${ }^{1}$

\section{Materials and methods}

After approval by our local Hospital Human Investigation Committee and after written informed consent by all participating parturients, the present study was conducted in 450 (three groups of 150) morbidly obese [(body mass index $(\mathrm{BMI})>35)$ - BMI $=$ weight in $\mathrm{kg} \cdot$ height $^{-2}$ in meters $]^{2}$ obstetric patients undergoing epidural analgesia during labour. Epidural catheterization was performed on 450 parturients randomized to one of three groups - sitting, lateral recumbent horizontal or lateral recumbent headdown positions, employing each posture throughout the entire duration of each successive day, until completion of the study, with 150 women in each group.

A Portex Minipack epidural system, containing an 18-G Tuohy epidural needle, a flexible radio-opaque epidural catheter with a blunt end and three helically placed side-holes near the tip, and a disposable plastic syringe assembly (SIMS PORTEX Ltd., Hythe, Kent, UK) was used throughout the study.

Group I: 150 patients; mean BMI 38.0; epidural puncture and catheter insertion were performed with the patient in a sitting position.

Group II: 150 patients; mean BMI 38.0; epidural puncture and catheter insertion were performed with the patient in a lateral recumbent horizontal position.
Group III: 150 patients; mean BMI 37.0; epidural puncture and catheter insertion were performed with the patient in a lateral recumbent $25^{\circ}-30^{\circ}$ head-down position on an electric obstetric bed (head-down angle established using a plastic $30^{\circ}$ angled triangle (Rotring Primus* protractor).

The Tuohy needle was inserted in the second or third lumbar interspace by a mid-line approach, with the needle orifice directed cephalad; the epidural space was identified by loss of resistance using an air-filled plastic syringe. In 24 instances over the three groups where the skin to epidural space distance exceeded 8 $\mathrm{cm}$, a longer Tuohy needle $-9.5 \mathrm{~cm} \times 18-\mathrm{G}$ was employed. After identification of the epidural space, and in the absence of blood or cerebrospinal fluid at the needle's hub, the catheter was threaded through the needle to a depth of $4 \mathrm{~cm}$ beyond the distal needle orifice, the needle was withdrawn and the catheter withdrawn so that a calculated $3 \mathrm{~cm}$ length remained in the epidural space. Any free flow of blood at the needle hub prior to catheter insertion was regarded as evidence of blood vessel puncture. Should needle or catheter insertion be accompanied by blood in the needle or catheter, the needle and catheter assembly was withdrawn and the procedure repeated at another interspace more cephalad. Thereafter, all patients were placed in the left lateral recumbent horizontal position and a $3-\mathrm{mL}$ test dose of lidocaine $2 \%(60 \mathrm{mg})$ was injected through the catheter and the patient was observed for the development of sensory blockade in 
the $\mathrm{L}_{2}$ or lower dermatomes, or for the inability to move the toes as evidence of unintentional subarachnoid injection. ${ }^{3}$ Patients were simultaneously assessed for symptoms of central nervous system irritability produced by subtoxic doses of lidocaine as an indication of unintentional intravascular injection. ${ }^{4}$

\section{Statistical analysis}

Primary outcome was occurrence of blood in the epidural catheter. Other related variables (secondary outcomes) were blood on the needle puncture, accidental subarachnoid puncture and more than one attempt at epidural cannulation. Statistical tests were carried out on three pairwise differences: sitting $v s$ lateral horizontal, sitting $v s$ lateral head-down, and lateral horizontal vs lateral head-down position using Pearson's Chi-square test with Yates' continuity correction. The Tukey-Kramer procedure was used to correct for multiple comparisons. ${ }^{5}$

\section{Results}

Accidental intravascular cannulation (primary outcome) and secondary outcomes (blood vessel puncture, unintentional subarachnoid puncture and number of patients requiring more than one attempt at epidural cannulation) in the three different positions are shown in Tables I and II.

The incidence of unintentional vessel cannulation was significantly less with the patient in the lateral recumbent head-down position (1.3\%), than in the sitting position (12.0\%). The incidence of secondary outcomes (blood in the catheter, blood in the needle, and accidental spinal puncture) is also shown in Table I.

A comparison of background variables in the three study groups is shown in Table II.

\section{Discussion}

Our results are in accord with those of our previous report and likewise demonstrate, in obese parturients, a significant reduction in epidural venous cannulation when the procedure is performed in the lateral recumbent head-down position, compared with the sitting or lateral recumbent horizontal positions. ${ }^{1}$

Our original misgivings that gross obesity and increased sc fat, by obscuring the usual bony landmarks of the supraspinous processes, would cause difficulty in identifying the mid-line and increase the risk of blood vessel puncture or unintentional dural puncture, were not borne out by the results of this study.

Obesity has been defined as a condition of excessive body fat, with a rather arbitrary difference between normality and obesity, but where the amount of fat tissue is so much increased that the mental and physical health are impaired, and that ultimately life expectancy is reduced. 6,7

The BMI has come to be regarded as a robust measure of the relationship between weight and height and is widely used in epidemiological and clinical studies, with a BMI of $<25 \mathrm{~kg} \cdot \mathrm{m}^{-2}$ being considered normal. Patients with a BMI of $>30,>35$ and $>55$ $\mathrm{kg} \cdot \mathrm{m}^{-2}$ are considered to be obese, morbidly obese and super-morbidly obese, respectively. ${ }^{2}$

The pathophysiology of obesity and its anesthetic implications have been extensively reviewed, with detailed consideration of the many and particular difficulties likely to be encountered in the obese obstetric and gynecological patient. ${ }^{8-10}$

There is a consensus that, if at all possible, general anesthesia should be avoided in the obese pregnant patient, with due attention being paid to technical difficulties in placing the epidural catheter in the presence of morbid obesity. A sensible recommendation has been the insertion of an epidural catheter early in labour in an obese parturient, thus allowing the anesthesiologist to establish good analgesia in a calm, controlled atmosphere, rather than hurrying in the event of an emergency situation.

It should be noted that, in the present study, the incidence of unintentional subarachnoid needle puncture in the 150 patients in the lateral recumbent headdown position was $2 \%$ - three patients - which compares unfavourably with the single patient $(0.3 \%)$ in the same position in our earlier study of non-obese parturients. ${ }^{1}$

Despite a slightly higher subarachnoid puncture rate, which was not statistically significant and remains lower than the spinal puncture rate reported in other series $(0.4 \%-6.0 \%)$, we conclude that gross obesity, per $s e$, should not be the reason to exclude morbidly obese parturients from the potential advantages of epidural anesthesia. Catheter insertion in the lateral recumbent head-down position, by reducing venous congestion in the epidural veins, minimizes the incidence of epidural vessel puncture or accidental venous cannulation and its consequences.

\section{Acknowledgement}

We are indebted to Fredrica Gendler for her meticulous secretarial assistance.

\section{References}

1 Bahar M, Chanimov M, Cohen ML, et al. Lateral recumbent head-down posture for epidural catheter insertion reduces intravascular injection. Can J Anesth 2001; 48: 48-53.

2 Bray GA. Pathophysiology of obesity. Am J Clin Nutr 
1992; 55: 488S-94S.

3 Colonna-Romano P, Lingaraju N, Braitman LE. Epidural test dose: lidocaine $100 \mathrm{mg}$, not chloroprocaine, is a symptomatic marker of iv injection in labouring parturients. Can J Anaesth 1993; 40: 714-7.

4 Michels AM, Lyons G, Hopkins PM. Lignocaine test dose to detect intravenous injection. Anaesthesia 1995; 50: 211-3.

5 Hochberg $\Upsilon$, Tambane AC. Multiple Comparison Procedures. New York: Wiley; 1978: 275, 407.

6 National Institutes of Health Consensus Development Conference Statement. Health implications of obesity. Ann Int Med 1985; 103: 147-51.

7 National Task Force on the Prevention and Treatment of Obesity. Overweight, obesity and health risk. Arch Intern Med 2000; 160: 898-904.

8 Fisher A, Waterhouse TD, Adams AP. Obesity: its relation to anesthesia. Anaesthesia 1975; 30: 633-47.

9 Adams JP, Murphy PG. Obesity in anaesthesia and intensive care. Br J Anaesth 2000; 85: 91-108.

10 Hood DD, Dewan DM. Anesthetic and obstetric outcome in morbidly obese parturients. Anesthesiology 1993; 79: 1210-8. 